\title{
3D image-based numerical computations of snow permeability: links to specific surface area, density, and microstructural anisotropy.
}

N. Calonne, C. Geindreau, F. Flin, S. Morin, B. Lesaffre,

S. Rolland du Roscoat and P. Charrier.

\section{Auxiliary Materials}




\section{Table of Contents and General Information}

\section{Table of Contents}

List of the 35 samples used in the study ............................................... p. 3

Computed values for the 35 samples used in the study................................ p. 4

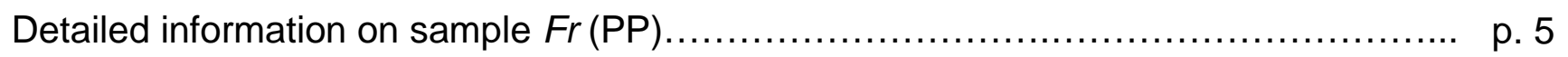

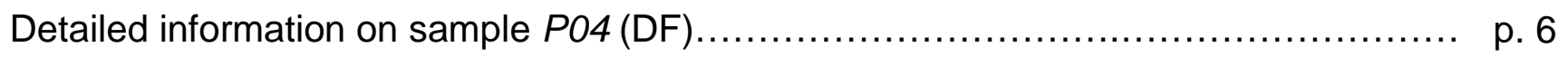

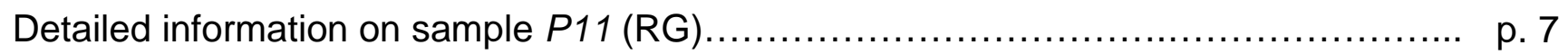

Detailed information on sample $\mathrm{H} 02$ (MF) ............................................ p. 8

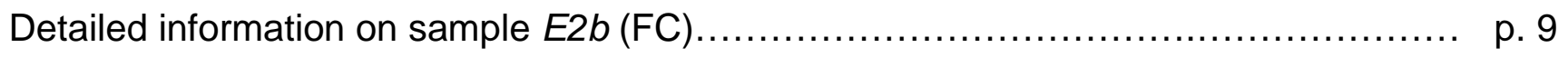

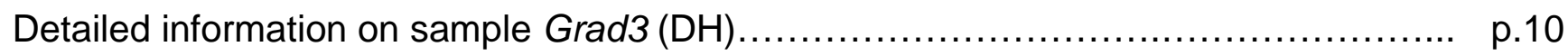

\section{General Information}

In the following, we provide the list of the samples used in this study with related information (Table 1) and values of permeability, density and specific surface area (Table 2). For each snow type [Fierz et al., 2009], a typical microtomographic sample is presented together with its REV estimate in term of permeability:

- Figures 1.a - 6.a: 3D images of the snow sample. The color levels of the images corresponds to the curvature field, which allows an easy representation of the 3D structure from planar images.

- Figures 1.b - 6.b: Estimations of the REV (the smallest fraction of the sample volume from which a variable representative of the whole can be determined) with respect to the permeability. It is estimated by calculating values of permeability from several subvolumes of increasing sizes. The REV is reached as soon as values remain constant when sub-volumes of calculations increase. In each figure, the permeability value computed on the largest volume size corresponds to that given in Table 2. 


\section{List of the 35 Samples Used in the Study}

\begin{tabular}{|c|c|c|c|c|}
\hline $\begin{array}{c}\text { Sample } \\
\text { name }\end{array}$ & $\begin{array}{c}\text { Snow } \\
\text { type }\end{array}$ & $\begin{array}{c}\text { Voxel } \\
\text { size } \\
\left(\mu \mathrm{m}^{3}\right)\end{array}$ & Remarks & Main References \\
\hline $\mathrm{Fr}$ & PP & 4.91 & Sampled at Col de Porte', 14 February 2002. & Calonne et al., 2011 \\
\hline 101 & PP & 4.91 & Sampled at Col de Porte, $15 \mathrm{~h}$ after the snowfall. & Flin et al., 2004 \\
\hline 103 & PP & 4.91 & $62 \mathrm{~h}$ after the snowfall, under isothermal conditions at $-2^{\circ} \mathrm{C}$. & Flin et al., 2004 \\
\hline 104 & PP & 4.91 & $81 \mathrm{~h}$ after the snowfall, under isothermal conditions at $-2^{\circ} \mathrm{C}$. & Flin et al., 2004 \\
\hline 108 & $\mathrm{DF}$ & 4.91 & $297 \mathrm{~h}$ after the snowfall, under isothermal conditions at $-2^{\circ} \mathrm{C}$. & Flin et al., 2004 \\
\hline 115 & $R G$ & 4.91 & $806 \mathrm{~h}$ after the snowfall, under isothermal conditions at $-2^{\circ} \mathrm{C}$. & Flin et al., 2004 \\
\hline 119 & $R G$ & 4.91 & $1381 \mathrm{~h}$ after the snowfall, under isothermal conditions at $-2^{\circ} \mathrm{C}$. & Flin et al., 2004 \\
\hline 121 & $R G$ & 4.91 & $1694 \mathrm{~h}$ after the snowfall, under isothermal conditions at $-2^{\circ} \mathrm{C}$. & Flin et al., 2004 \\
\hline 123 & $R G$ & 4.91 & $2026 \mathrm{~h}$ after the snowfall, under isothermal conditions at $-2^{\circ} \mathrm{C}$. & Flin et al., 2004 \\
\hline $\mathrm{P} 03$ & $\mathrm{PP}$ & 8.48 & Girose glacier $^{2}, 20$ cm depth, 17 March 2009. & Flin et al., 2011 \\
\hline P04 & DF & 8.588 & Girose glacier, 40 cm depth, 17 March 2009. & Flin et al., 2011 \\
\hline P06 & $R G$ & 6.158 & Girose glacier, $60 \mathrm{~cm}$ depth, 17 March 2009. & Flin et al., 2011 \\
\hline $\mathrm{P} 07$ & $R G$ & 8.609 & Girose glacier, 70 cm depth, 17 March 2009. & Flin et al., 2011 \\
\hline P08 & $R G$ & 8.552 & Girose glacier, 100 cm depth, 17 March 2009. & Flin et al., 2011 \\
\hline P09 & $R G$ & 6.158 & Girose glacier, 120 cm depth, 17 March 2009. & Flin et al., 2011 \\
\hline $\mathrm{P} 10$ & $R G$ & 6.103 & Girose glacier, 165 cm depth, 17 March 2009. & Flin et al., 2011 \\
\hline $\mathrm{P} 11$ & $R G$ & 8.588 & Girose glacier, 65 cm depth, 1 March 2009. & Flin et al., 2011 \\
\hline $\mathrm{P} 14$ & $R G$ & 6.154 & Girose glacier, 80 cm depth, 1 March 2009. & Flin et al., 2011 \\
\hline $\mathrm{P} 15$ & $R G$ & 6.158 & Girose glacier, $170 \mathrm{~cm}$ depth, 1 March 2009. & Flin et al., 2011 \\
\hline $\mathrm{H} 00$ & $R G$ & 8.609 & Sieved snow, followed by isothermal conditions. & Flin et al., 2011 \\
\hline $\mathrm{H} 01$ & MF & 8.609 & Grain coarsening of water-saturated snow and drainage after $1 \mathrm{~h}$. & Flin et al., 2011 \\
\hline $\mathrm{H} 1-2$ & MF & 8.590 & Grain coarsening of water-saturated snow and drainage after $6 \mathrm{~h}$. & Flin et al., 2011 \\
\hline $\mathrm{H} 02$ & MF & 8.590 & Grain coarsening of water-saturated snow and drainage after $24 \mathrm{~h}$. & Flin et al., 2011 \\
\hline $\mathrm{H} 03$ & MF & 8.609 & Grain coarsening of water-saturated snow and drainage after $48 \mathrm{~h}$. & Flin et al., 2011 \\
\hline H05-G & MF & 9.46 & Grain coarsening of water-saturated snow and drainage after $142 \mathrm{~h}$. & Flin et al., 2011 \\
\hline Chamair & MF & 10 & Grain coarsening of water-saturated snow and drainage. & Coléou et al., 2001 \\
\hline $\mathrm{E} 2 \mathrm{~b}$ & FC & 4.91 & 3 weeks under a TG $=16 \mathrm{~K} \mathrm{~m}^{-1}, \mathrm{~T}_{\text {mean }}=-3^{\circ} \mathrm{C}$, sampled in the middle of the layer. & Flin et al., 2008 \\
\hline$O A$ & RG & 8.392 & Sieved snow, following by isothermal conditions. & This study \\
\hline $1 \mathrm{~A}$ & $\mathrm{RG}$ & 8.395 & 3 days under a $T G=43 \mathrm{~K} \mathrm{~m}^{-1}, T_{\text {mean }}=-4^{\circ} \mathrm{C}$, sampled in the middle of the layer. & This study \\
\hline $2 \mathrm{~A}$ & FC & 8.373 & 6 days under a $T G=43 \mathrm{~K} \mathrm{~m}^{-1}, T_{\text {mean }}=-4^{\circ} \mathrm{C}$, sampled in the middle of the layer. & This study \\
\hline $3 \mathrm{~A}$ & $\mathrm{DH}$ & 8.400 & 9 days under a $T G=43 \mathrm{~K} \mathrm{~m}^{-1}, T_{\text {mean }}=-4^{\mathrm{C}} \mathrm{C}$, sampled in the middle of the layer. & Calonne et al., 2011 \\
\hline $4 \mathrm{~A}$ & $\mathrm{DH}$ & 8.397 & 13 days under a $T G=43 \mathrm{~K} \mathrm{~m}^{-1}, T_{\text {mean }}=-4^{\circ} \mathrm{C}$, sampled in the middle of the layer. & Calonne et al., 2011 \\
\hline $5 A-G$ & $\mathrm{DH}$ & 9.655 & 17 days under a $T G=43 \mathrm{~K} \mathrm{~m}^{-1}, T_{\text {mean }}=-4^{\circ} \mathrm{C}$, sampled in the middle of the layer. & This study \\
\hline $7 A-G$ & $\mathrm{DH}$ & 9.672 & 21 days under a $T G=43 \mathrm{~K} \mathrm{~m}^{-1}, T_{\text {mean }}=-4^{\circ} \mathrm{C}$, sampled in the middle of the layer. & This study \\
\hline Grad3 & $\mathrm{DH}$ & 10 & 8 days under a $\mathrm{TG}=100 \mathrm{~K} \mathrm{~m}^{-1}, \mathrm{~T}_{\text {mean }}=-5^{\circ} \mathrm{C}$ & Coléou et al., 2001 \\
\hline
\end{tabular}

Table 1: List of the 35 snow samples used in the present work. Snow type is defined according to the International Classification for Seasonal Snow on the Ground [Fierz et al., 2009]: PP, Precipitation Particles; DF, Decomposing and Fragmented precipitation particles; RG, Rounded Grains; FC, Faceted Crystals; DH, Depth Hoar; MF, Melt Forms. Lines with gray background correspond to samples for which detailed information is provided below.

\footnotetext{
$1325 \mathrm{~m}$ altitude, Chartreuse range, France.

${ }^{2} 3200 \mathrm{~m}$ altitude, Ecrins range, France.
} 


\section{Computed Values for the 35 Samples Used in the Study}

\begin{tabular}{|c|c|c|c|c|c|c|}
\hline Sample name & $\begin{array}{c}\text { Snow } \\
\text { type }\end{array}$ & $K_{x} \times 10^{-9}\left(\mathrm{~m}^{2}\right)$ & $K_{y} \times 10^{-9}\left(\mathrm{~m}^{2}\right)$ & $K_{z} \times 10^{-9}\left(\mathrm{~m}^{2}\right)$ & SSA $\left(\mathrm{m}^{2} \mathrm{~kg}^{-1}\right)$ & Density $\left(\mathrm{kg} \mathrm{m}^{-3}\right)$ \\
\hline $\mathrm{Fr}$ & PP & 3.58 & 3.77 & 3.69 & 55.30 & 120.49 \\
\hline 101 & PP & 3.83 & 2.22 & 3.33 & 55.79 & 102.90 \\
\hline 103 & $\mathrm{PP}$ & 3.79 & 3.93 & 4.03 & 41.37 & 123.34 \\
\hline 104 & PP & 4.23 & 4.16 & 4.06 & 42.48 & 113.43 \\
\hline 108 & DF & 4.60 & 4.38 & 4.79 & 29.32 & 147.71 \\
\hline 115 & $R G$ & 4.54 & 4.70 & 4.79 & 23.32 & 172.76 \\
\hline 119 & $\mathrm{RG}$ & 4.73 & 4.82 & 4.84 & 19.90 & 192.48 \\
\hline 121 & $R G$ & 4.73 & 4.93 & 4.36 & 19.23 & 198.62 \\
\hline 123 & $R G$ & 2.82 & 2.62 & 2.47 & 17.24 & 256.30 \\
\hline P03 & PP & 2.42 & 2.38 & 2.06 & 50.91 & 134.55 \\
\hline P04 & DF & 6.14 & 6.38 & 4.62 & 25.36 & 157.54 \\
\hline P06 & $R G$ & 0.64 & 0.65 & 0.59 & 21.59 & 354.51 \\
\hline P07 & $R G$ & 2.45 & 2.44 & 1.83 & 17.15 & 280.05 \\
\hline P08 & $R G$ & 1.09 & 1.08 & 0.96 & 14.57 & 379.00 \\
\hline P09 & $R G$ & 1.26 & 1.29 & 1.04 & 12.29 & 396.14 \\
\hline P10 & $R G$ & 1.55 & 1.68 & 1.38 & 10.46 & 396.07 \\
\hline P11 & $R G$ & 0.46 & 0.45 & 0.40 & 20.76 & 413.75 \\
\hline $\mathrm{P} 14$ & $R G$ & 0.90 & 0.88 & 0.80 & 18.13 & 352.68 \\
\hline P15 & $R G$ & 1.54 & 1.54 & 1.73 & 16.09 & 315.54 \\
\hline $\mathrm{HOO}$ & $R G$ & 0.45 & 0.44 & 0.43 & 17.34 & 431.36 \\
\hline $\mathrm{H} 01$ & MF & 0.48 & 0.45 & 0.48 & 6.99 & 550.93 \\
\hline $\mathrm{H} 1-2$ & MF & 0.75 & 0.75 & 0.74 & 7.69 & 503.80 \\
\hline $\mathrm{H} 02$ & MF & 1.22 & 1.22 & 1.27 & 6.18 & 471.70 \\
\hline $\mathrm{HO3}$ & MF & 1.80 & 1.88 & 1.73 & 5.25 & 498.11 \\
\hline H05-G & MF & 3.96 & 4.57 & 4.87 & 3.78 & 471.70 \\
\hline Chamair & MF & 0.57 & 0.51 & 0.54 & 8.49 & 525.90 \\
\hline $\mathrm{E} 2 \mathrm{~b}$ & FC & 5.71 & 4.87 & 5.62 & 15.43 & 239.70 \\
\hline$O A$ & $R G$ & 0.76 & 0.78 & 0.70 & 27.68 & 314.81 \\
\hline $1 \mathrm{~A}$ & $R G$ & 1.75 & 1.74 & 1.64 & 23.37 & 275.01 \\
\hline $2 A$ & $\mathrm{FC}$ & 1.95 & 1.95 & 2.02 & 20.75 & 282.71 \\
\hline $3 A$ & $\mathrm{DH}$ & 2.98 & 2.89 & 3.08 & 18.18 & 274.82 \\
\hline $4 \mathrm{~A}$ & $\mathrm{DH}$ & 2.71 & 2.61 & 3.18 & 15.19 & 315.36 \\
\hline $5 A-G$ & $\mathrm{DH}$ & 3.77 & 3.70 & 4.39 & 14.89 & 284.09 \\
\hline $7 A-G$ & $\mathrm{DH}$ & 3.92 & 3.95 & 4.84 & 13.42 & 311.23 \\
\hline Grad3 & $\mathrm{DH}$ & 0.65 & 0.63 & 1.06 & 21.84 & 369.18 \\
\hline
\end{tabular}

Table 2: List of the snow samples and types with the corresponding computed values of the permeability in the $x, y$ and $z$ direction $\left(K_{x}, K_{y}\right.$ and $\left.K_{z}\right)$, the Specific Surface Area (SSA) and the density. All these values were computed on the largest volume available of each sample, which is at least equal to REV of the three variables. Snow type is defined according to the International Classification for Seasonal Snow on the Ground [Fierz et al., 2009]: PP, Precipitation Particles; DF, Decomposing and Fragmented precipitation particles; RG, Rounded Grains; FC, Faceted Crystals; DH, Depth Hoar; MF, Melt Forms. Lines with gray background correspond to samples for which detailed information is provided below. 


\section{Sample Fr - Precipitation Particles (PP)}

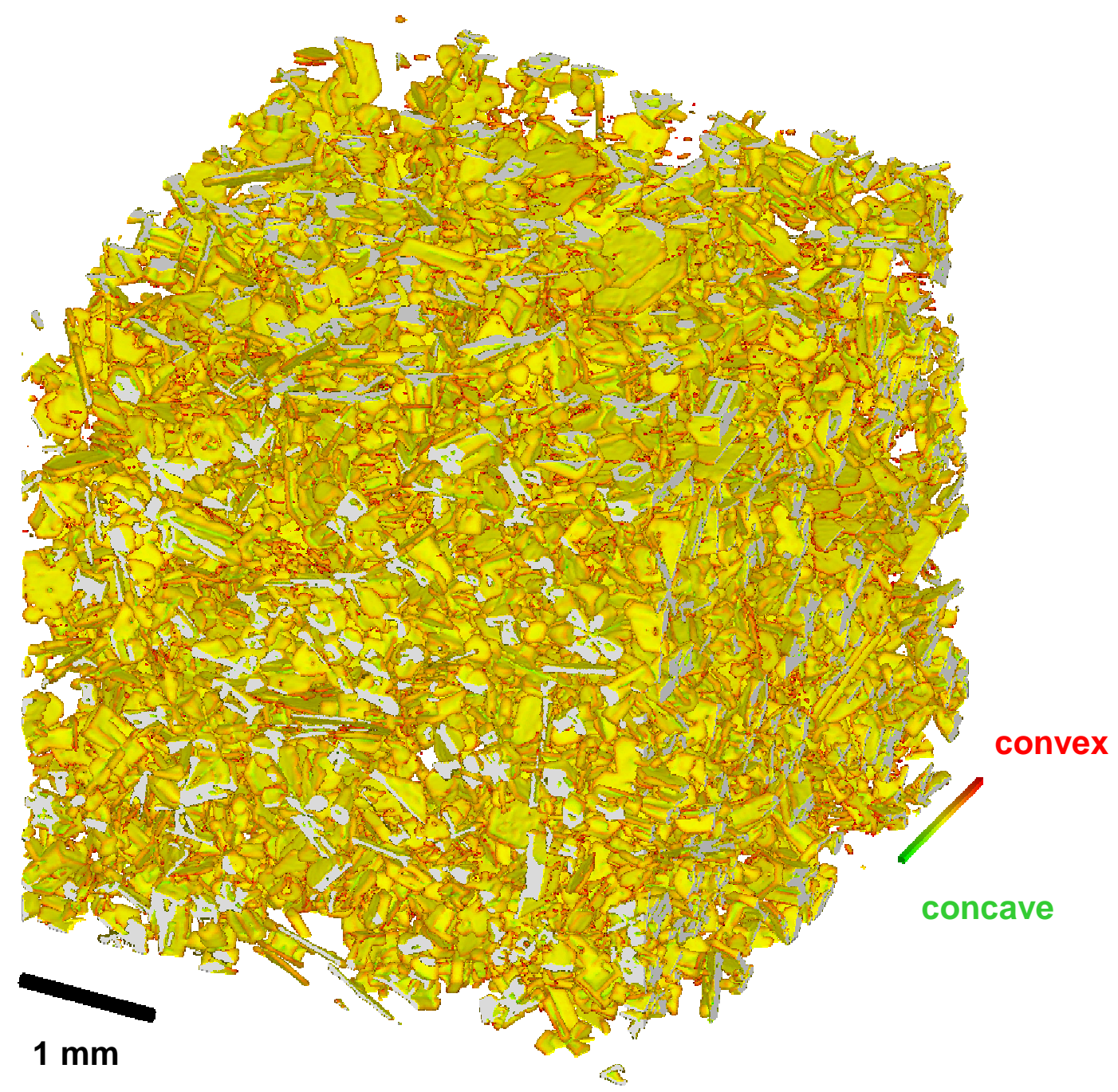

Figure 1.a: 3D visualization of the microtomographic image (size $=1192^{3}$ voxels, 1 vox. $\left.=4.91 \mu \mathrm{m}\right)$.

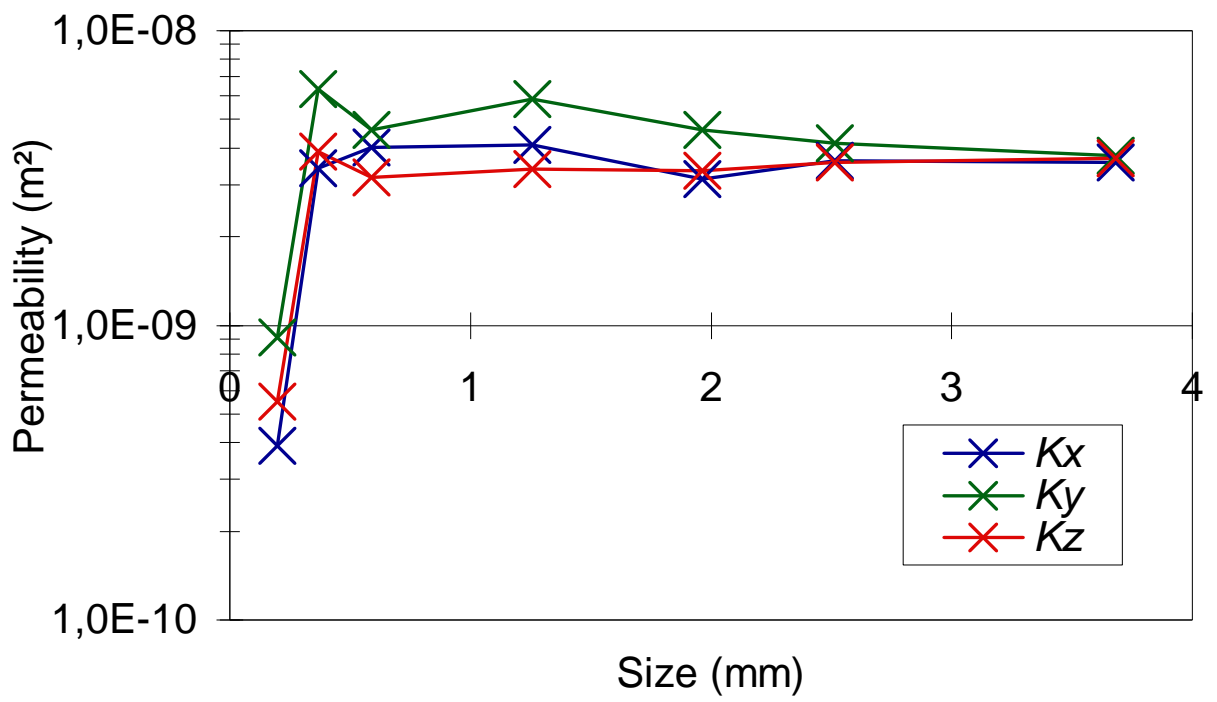

Figure 1.b:

Dependency of $\mathbf{K}$ estimates with sample size. 


\section{Sample P04 - Decomposing and Fragmented precipitation particles (DF)}

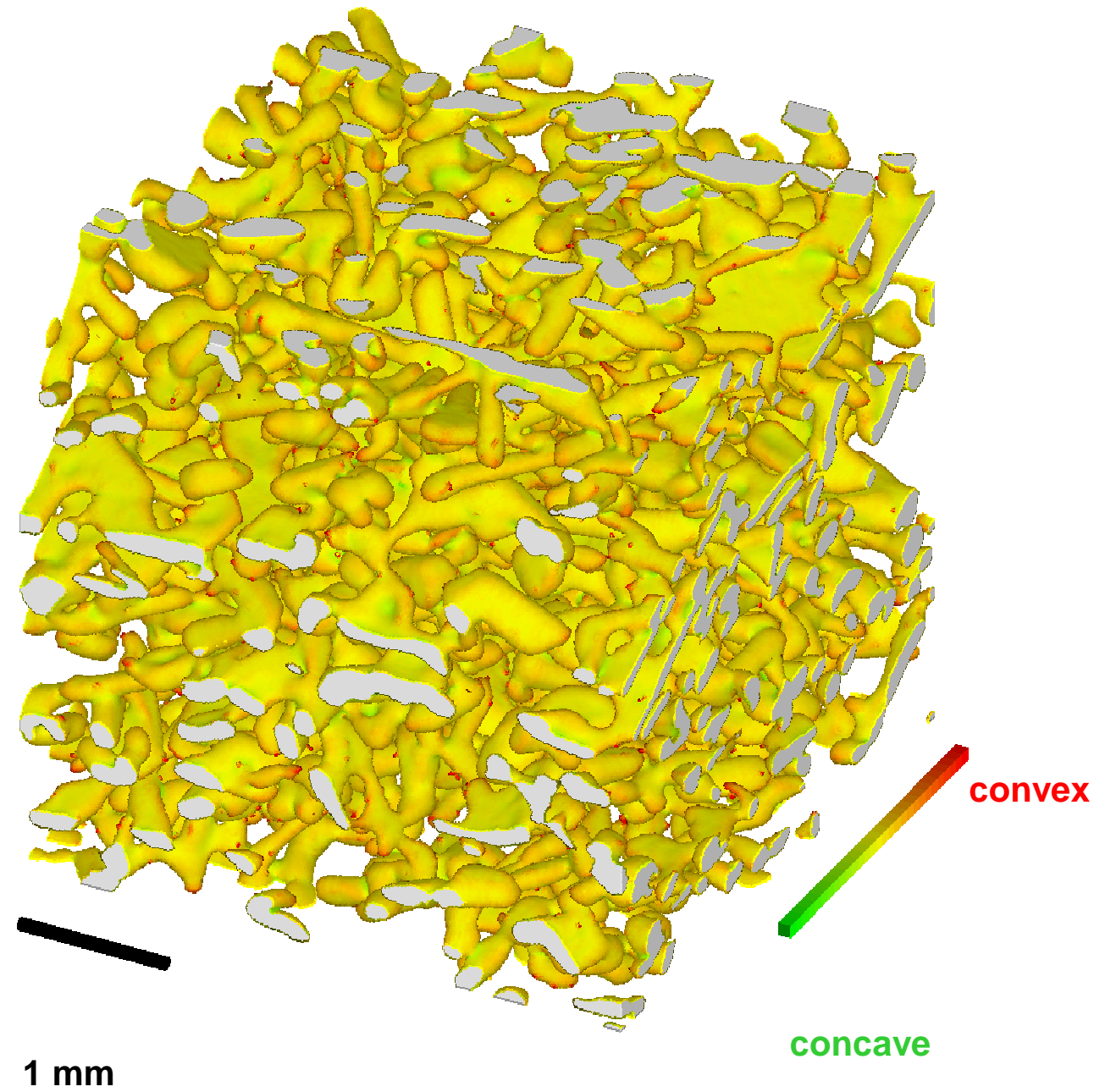

Figure 2.a: $3 \mathrm{D}$ visualization of the microtomographic image (size $=512^{3}$ voxels, 1 vox. $=8.588 \mu \mathrm{m}$ ).

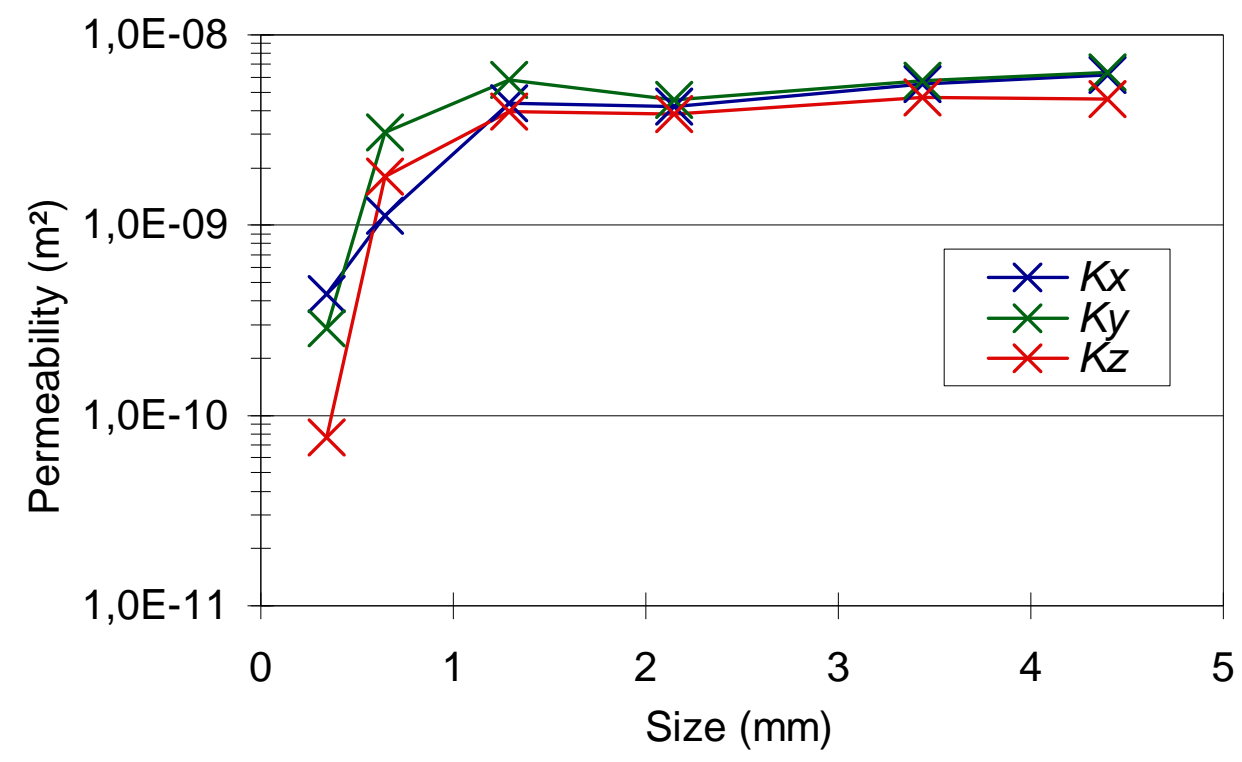

Figure 2.b:

Dependency of $\mathbf{K}$ estimates with sample size. 


\section{Sample P11 - Rounded Grains (RG)}

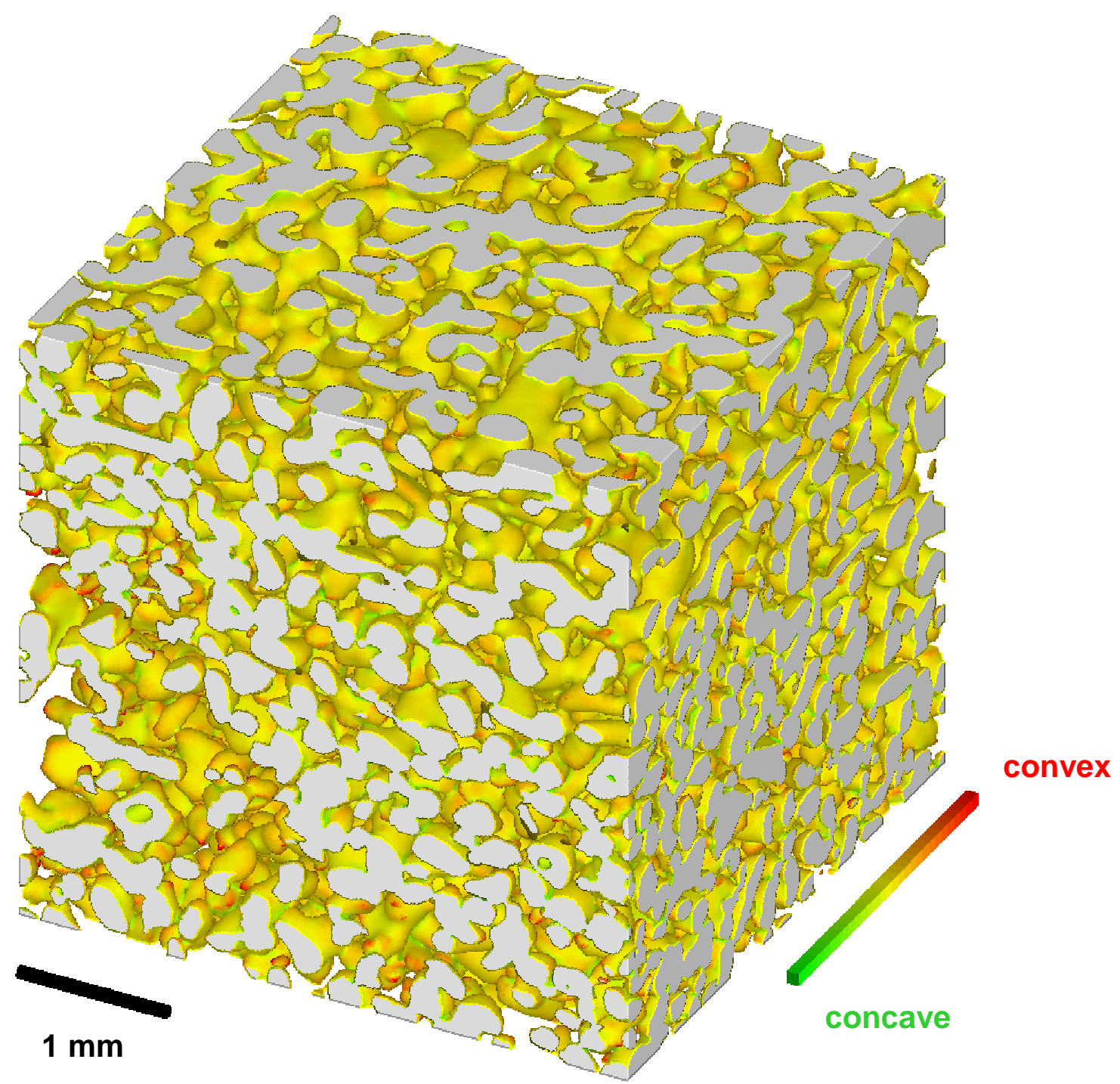

Figure 3.a: 3D visualization of the microtomographic image (size $=512^{3}$ voxels, 1 vox. $=8.588 \mu \mathrm{m}$ ).

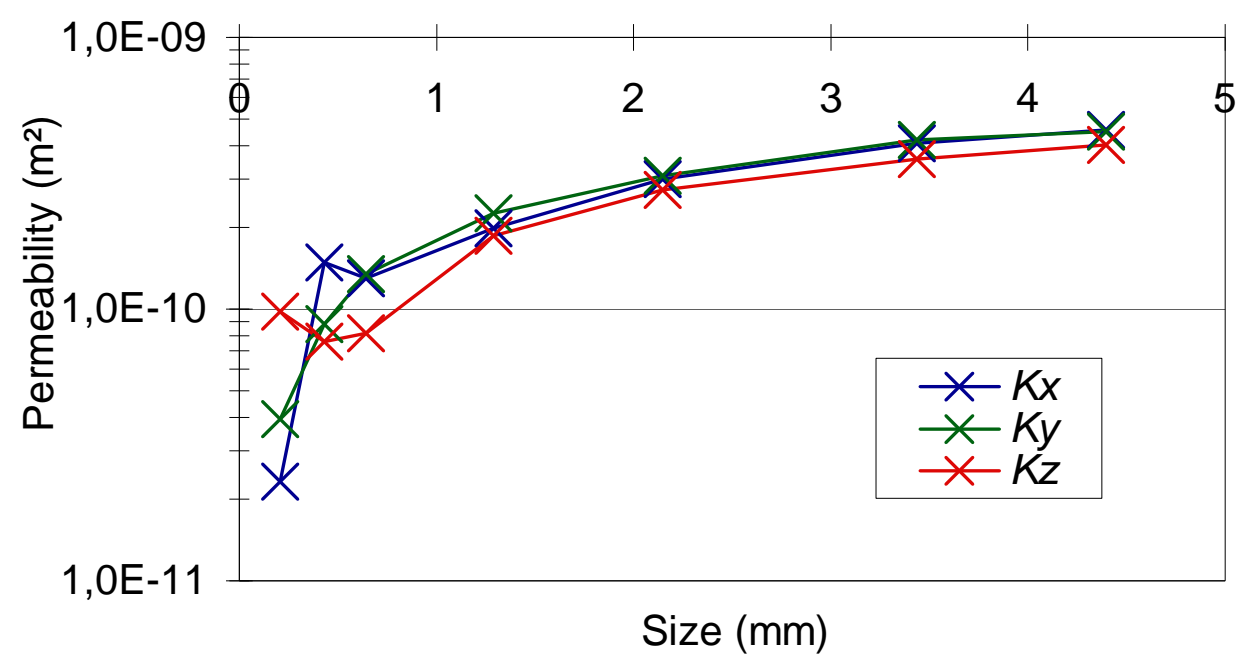

Figure 3.b:

Dependency of $\mathbf{K}$ estimates with sample size. 


\section{Sample HO2 - Melt Forms (MF)}

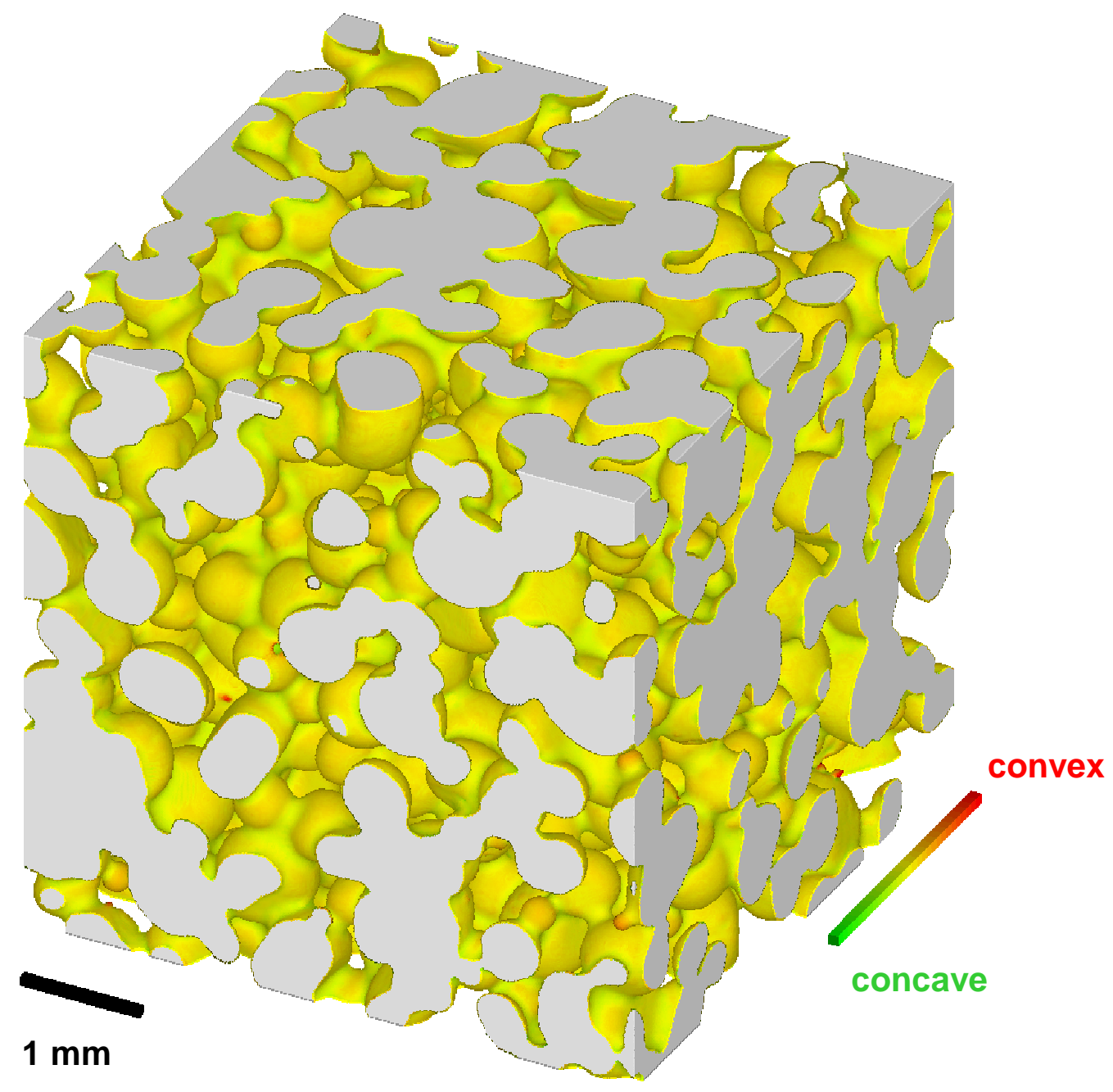

Figure 4.a: $3 D$ visualization of the microtomographic image (size $=651^{3}$ voxels, 1 vox. $=8.590 \mu \mathrm{m}$ )

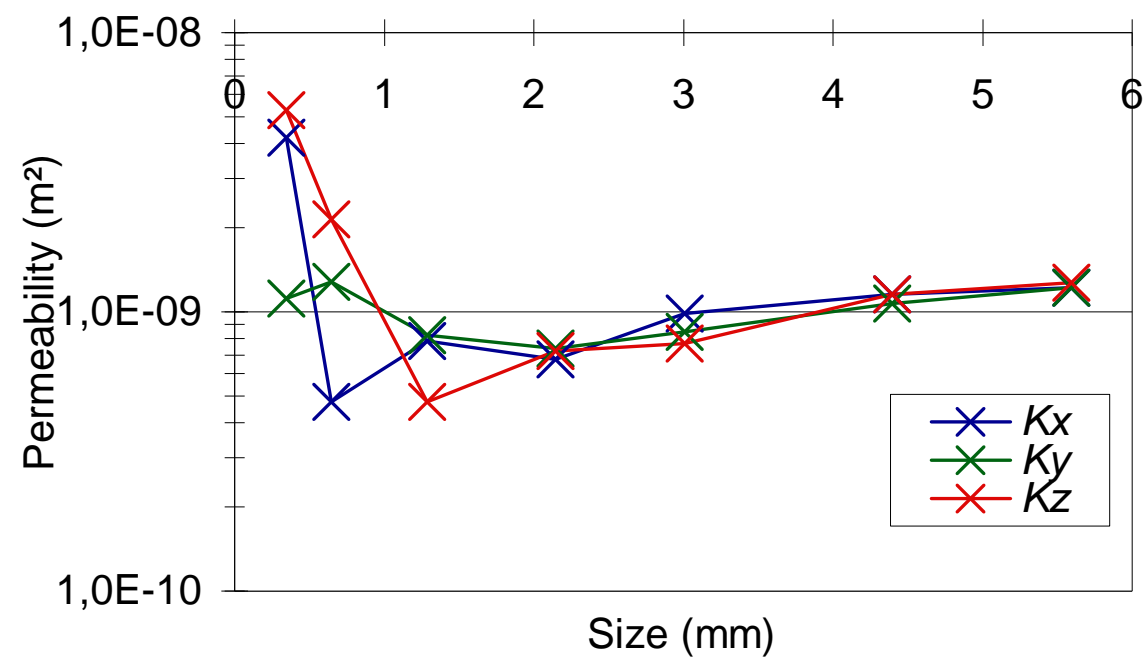

Figure 4.b:

Dependency of $\mathbf{K}$ estimates with sample size. 


\section{Sample E2b - Faceted Crystals (FC)}

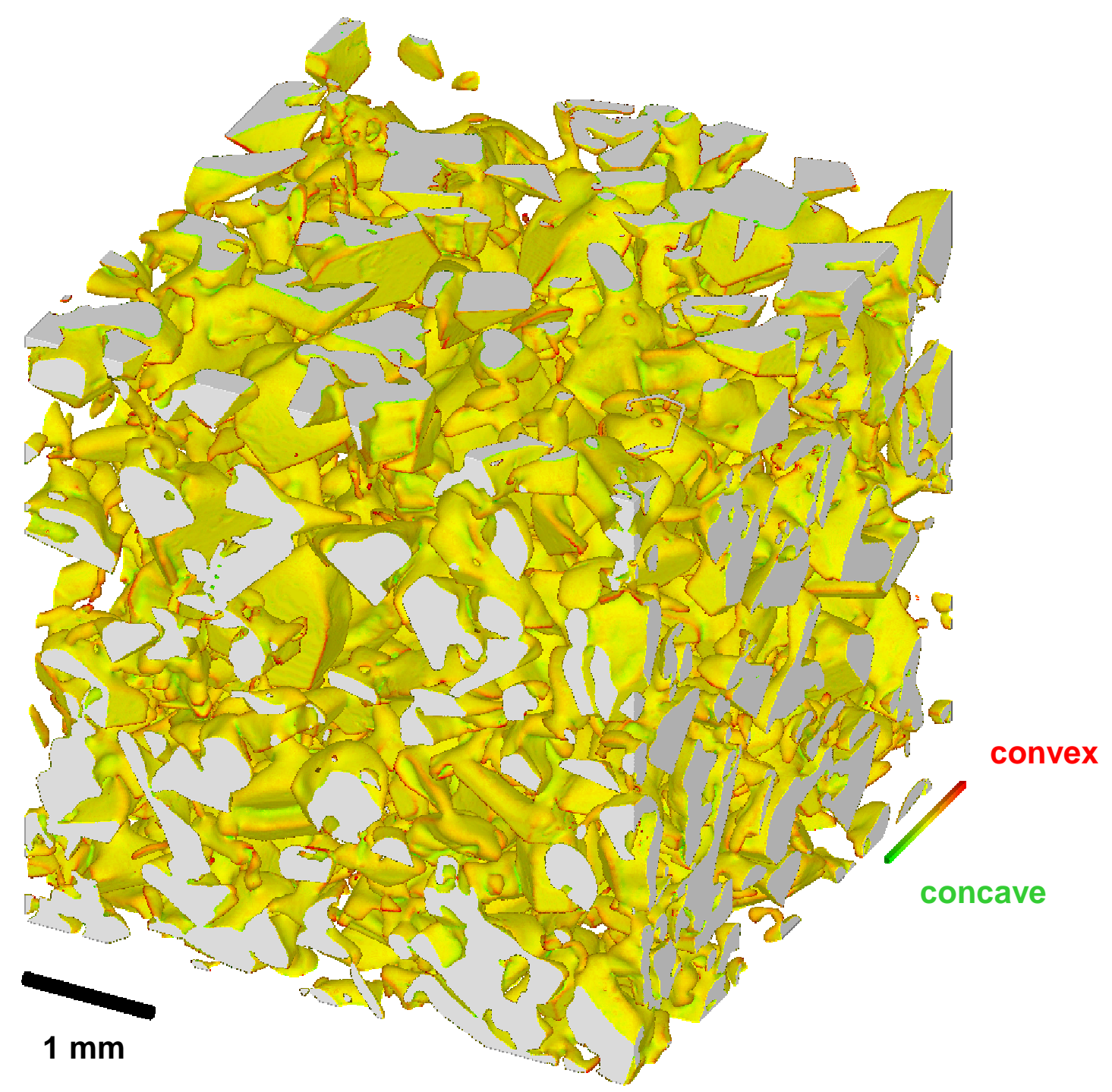

Figure 5.a: 3D visualization of the microtomographic image (size $=1200^{3}$ voxels, 1 vox. $=4.91 \mu \mathrm{m}$ )

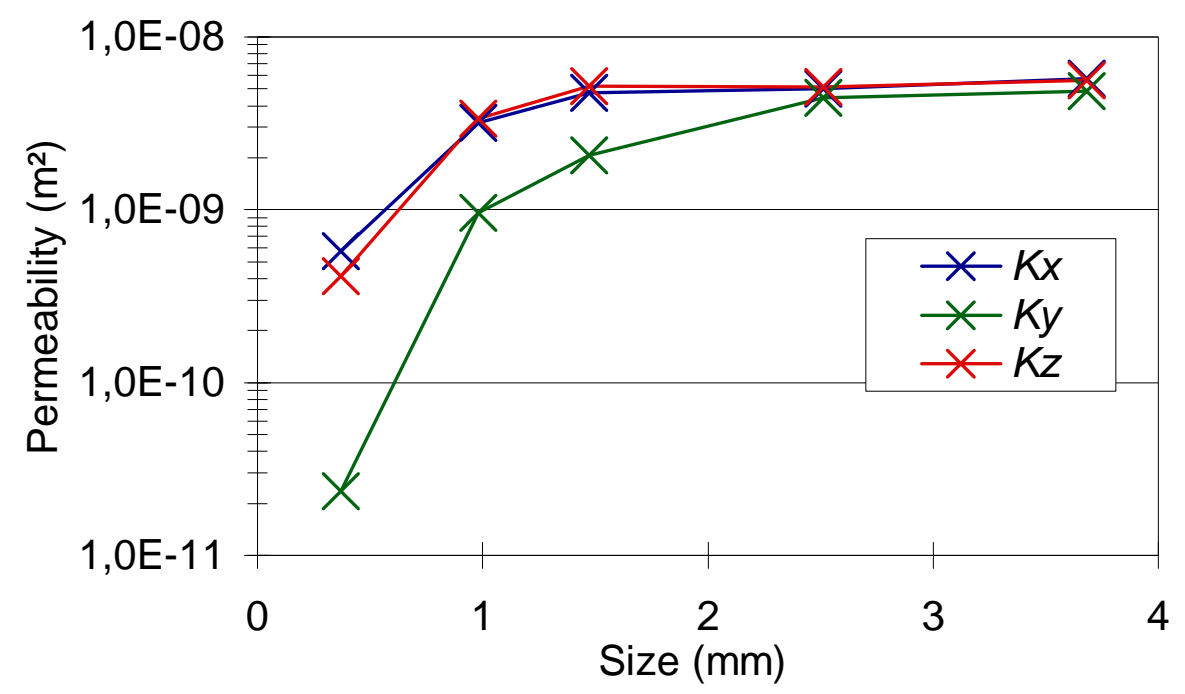

Figure 5.b:

Dependency of $\mathbf{K}$ estimates with sample size. 


\section{Sample Grad3 - Depth Hoar (DH)}

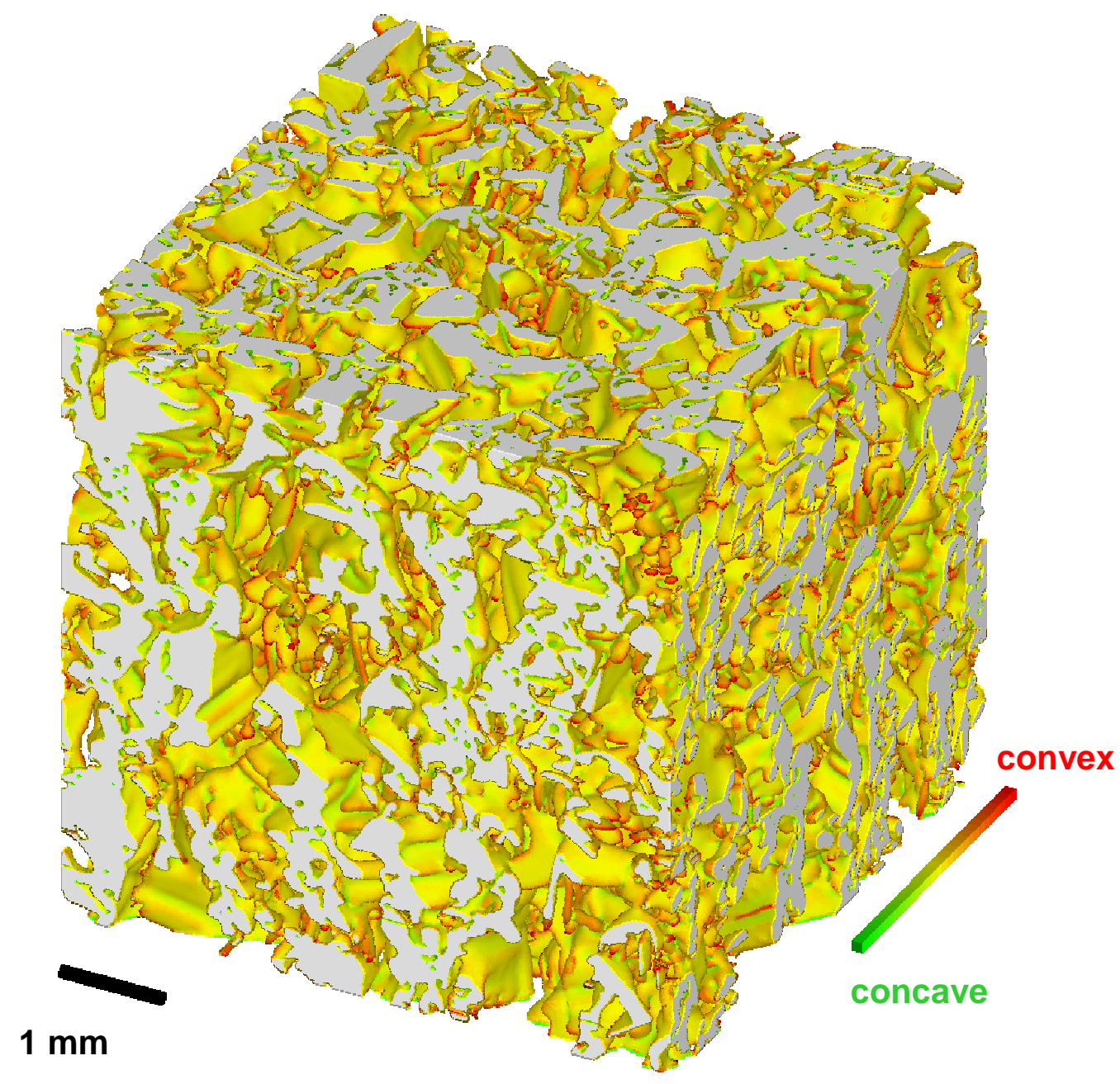

Figure 6.a: $3 \mathrm{D}$ visualization of the microtomographic image (size $=600^{3}$ voxels, 1 vox. $=10 \mu \mathrm{m}$ ).

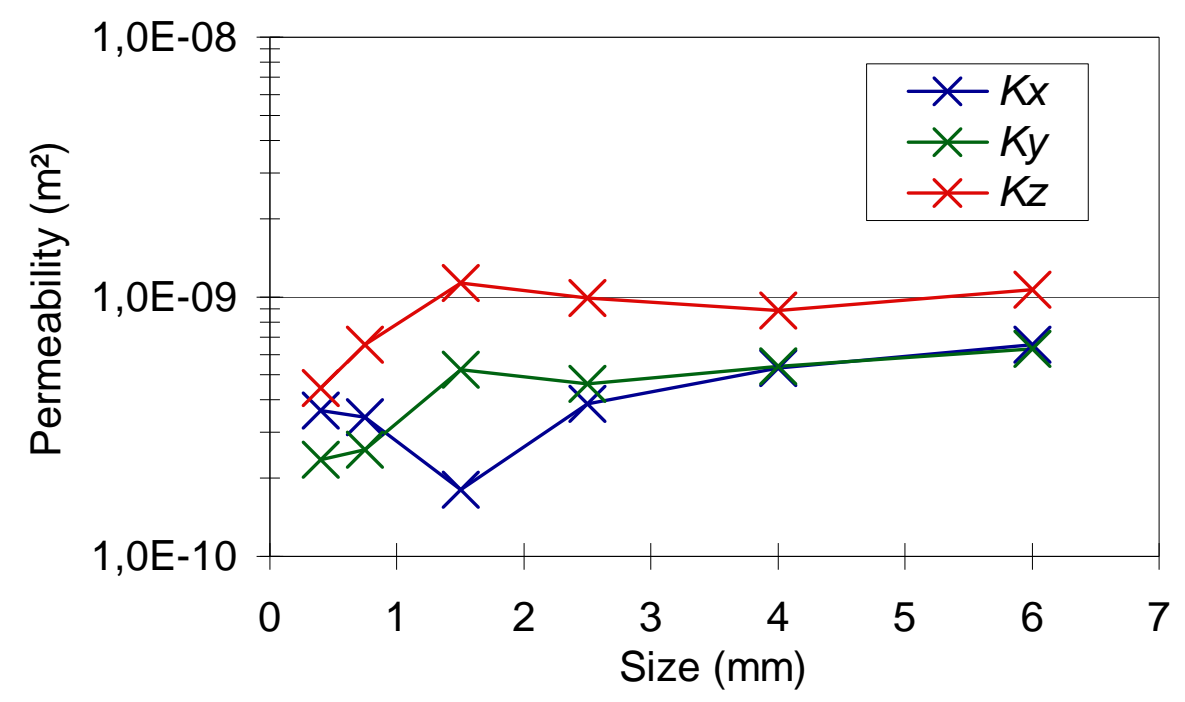

Figure 6.b:

Dependency of $\mathbf{K}$ estimates with sample size. 